\title{
CURRENT STATUS FORENSIC RECOGNITION OF MECHANISMS OF DAMAGES CERTAIN SPECIES OF AUTOMOTIVE INJURY
}

\author{
Golubovich L. L. , Golubovich A.L., Golubovich P. L., Zubko M.D., \\ A.V. Kurtev
}

\begin{abstract}
Resume. Changes in the political, social and economic life, especially in the last twenty five years, accompanied by a significant increase in Ukraine the number of lorries and cars, which is owned by companies and organizations as well as individuals. What is more import cars are especially in demand among the population. Import and domestic cars marked are significantly differing by increasing of speed and to some extent are equipped by security measures. At the same time requirements to comply with the rules of traffic safety on the roads and measures of punishment of violators become more severe. But in spite of everything the number of road accidents is increasing every year. In the article the modern possibilities and necessary conditions for a qualified decision of the mechanism of injury at a particular motor-road accident in the cabin of the modern car are done.
\end{abstract}

Keywords: trauma in the car, mechanism of injury, the driver and passenger.

УДК 612.12-001.45:340.624

\section{СУДОВО-МЕДИЧНА ОЦІНКА ТІЛЕСНИХ УШКОДЖЕНЬ У ПРОТЕСТУВАЛЬНИКІВ МАЙДАНУ}

\author{
СВ. Д. Мішалов \\ Національна медична академія післядипломної освіти імені П. Л. Шупика
}

\begin{abstract}
Резюме. У статті наведені особливості тілесних ушкоджень у протестувальників Майдану, що були виявлені під час судово-медичного огляду (освідування) 304 майданівців, травмованих під час активних подій 18-20 лютого 2014 р. Виявлено, що серед тілесних ушкоджень перше місце належить вогнепальній травмі, а саме таким її складовим як: садна, крововиливи, рани, спричинені еластичними кулями і картеччю до засобів ударно-травматичної дії та кулями, шротом і картеччю від вогнепальної зброї, 12 мм металевою кулею типу «Блондо», термічні, хімічні опіки, контузії, втрати зору і слуху, травматичні ампутації пальців рук від розриву світло-шумових гранат. Окрім цього, характер, об'єм та переважна локалізація ушкоджень дозволила вважати, що світло-шумові гранати були умисно і штучно споряджені «правоохоронцями» додатковими уражаючими компонентами, наслідками яких стали чисельні рани переважно на нижніх кінцівках. Переважною локалізацією ушкоджень були нижні кінцівки і голова. За ступенем тяжкості переважали легкі тілесні ушкодження.

Ключові слова: судово-медична експертиза, тілесні ушкодження, вогнепальна травма.
\end{abstract}

ВСТУП. Судово-медична експертиза вогнепальних ушкоджень залишається однією з актуальних проблем судової медицини. Важливість цього напрямку досліджень підтверджується подіями останніх років, зокрема під час подій на Майдані 2014 р. I хоча вогнепальній травмі присвячено дуже багато вітчизняних і зарубіжних наукових робіт (1-7), деякі аспекти їі морфологічних проявів потребують оцінки у дійсний час.

Минає вже третій рік з часу революції Гідності, а наслідки жорстокого ставлення влади В. Януковича та його «правоохоронців» до протестувальників Майдану не втратили свою актуальність й сьогодні, наприкінці 2016 року, оскільки винуватців злочину до кінця не виявлено і не покарано!!! В той час, як сотні осіб, що зазнали різних травмувань, - від побиття міліцейськими кийками до смертельних вогнепальних ушкоджень, - нам відомі, і чекають на справедливість. Саме тому Майдан забувати ще рано. Одним із таких наглядних спогадів про недавнє минуле може стати статистичний і фото- матеріал із власних джерел, що був отриманий нами під час судово-медичного огляду (освідування) 304 майданівців, травмованих переважно 18-20 лютого 2014 р.

Метою дослідження було виявлення особливостей тілесних ушкоджень,зокрема вогнепальної травми, у протестувальників Майдану, що була заподіяна «правоохоронцями» в період 18-20 лютого 2014 р.

Матеріал і методи дослідження. Матеріалом дослідження слугували результати власного судово-медичного огляду (освідування) 304 майданівців, що отримали травмування під час активних подій переважно 18-20 лютого 2014 р. Для обробки результатів дослідження були використані стандартні методи варіаційної статистики.

\section{РЕЗУЛЬТАТИ ДОСЛІДЖЕННЯ ТА ЇХ ОБГОВОРЕННЯ.}

3 ініціативи Асоціації незалежних адвокатів України для найскорішої фіксації тілесних ушкоджень у потерпілих протестувальників, як доказів злочину з боку так званих «правоохоронців», у найкоротші терміни після їх заподіяння, викладачі кафедр судової медицини Національної медичної академії післядипломної совіти (НМАПО) імені П. Л. Шупика і Національного медичного університету (НМУ) імені О. О. Богомольця (водночас члени Асоціації судових медиків України), провели судово-медичний огляд (освідування) 304 майданівців, що зазнали травмувань переважно 18-20 лютого 2014 р. Робота виконувалась у позаурочний час, протягом двох 
тижнів: 324 лютого по 07 березня 2014 р. у медичних пунктах на Хрещатику, спочатку у приміщенні кафе «Шато», а потім у «Будинку лікаря», де одночасно надавалась і медична допомога потерпілим. Після освідування потерпілим надавався «Висновок спеціаліста», у підсумках якого були вказані вид травми, давність і механізм ії утворення, ступінь тяжкості тілесних ушкоджень. В подальшому, цей документ міг бути підставою для звернення до слідчо-судових органів, щодо призначення судово-медичної експертизи і відкриття кримінального провадження за фактом заподіяного злочину.

Нами був виявлений широкий спектр тілесних ушкоджень: садна, синці, вогнепальні та забійні рани, які були спричинені еластичними кулями і картеччю до засобів ударно-травматичної дії та кулями, шротом і картеччю від вогнепальної зброї, 12 мм металевою кулею типу «Блондо», світло-шумовими гранатами і гумовими палицями. Термічні, хімічні опіки, контузії, втрати зору і слуху були спричинені від розриву світло-шумових гранат. Окрім цього, характер, об’єм та переважна локалізація ушкоджень дозволила вважати, що світло-шумові гранати були умисно і штучно споряджені «правоохоронцями» додатковими уражаючими компонентами, наслідками яких стали чисельні рани переважно на нижніх кінцівках. Частину фотоілюстрацій, що були включені до «Висновків спеціаліста», наводимо нижче (рис. 1 - 4).

Статистичний аналіз ушкоджень виявив, що із 304 обстежених протестувальників Майдану найбільшу кількість складали чоловіки - 287, жінок було 17 осіб.
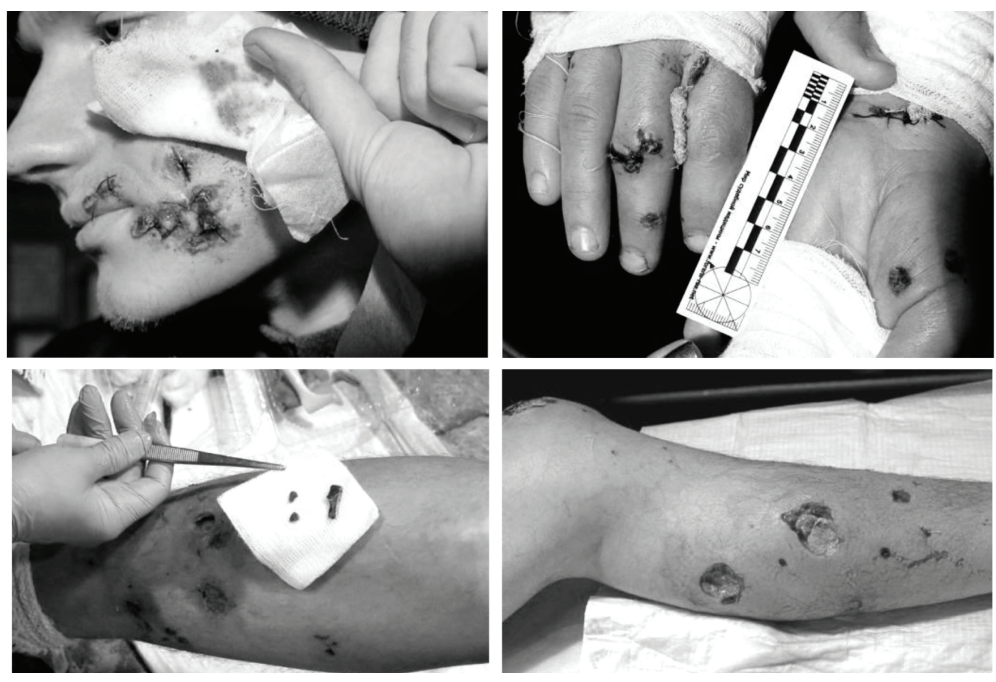

Рис. 1. Ушкодження від додаткових вражаючих елементів та уламків корпусу світло-шумових гранат
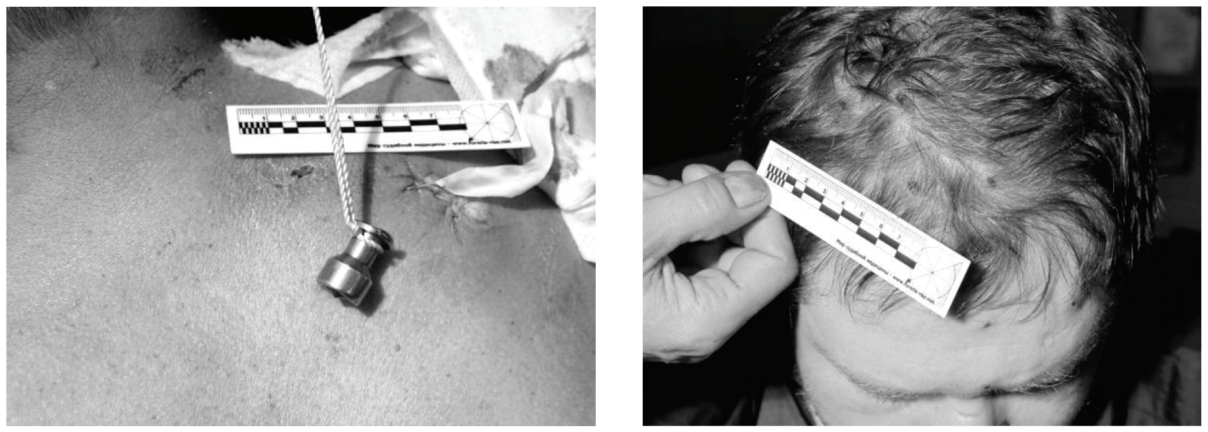

Рис. 2. Ушкодження 12 мм кулею типу «Блондо»

Рис. 3. Вогнепальні ушкодження свинцевим шротом
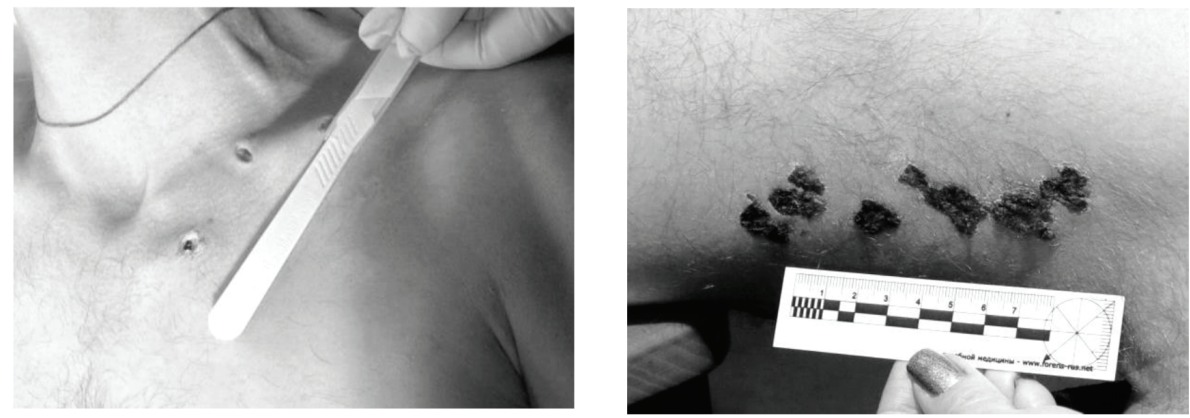

Рис. 4. Вогнепальні ушкодження еластичними кулями до засобів ударно-травматичної дії 
На загал, у кожного потерпілого визначались різні види травмувань: садна, синці, забиті рани, переломи кісток, опіки, різні вогнепальні ушкодження, травматична ампутація пальців. Конкретна статистична інформація наведена у графічному вигляді в абсолютних цифрах (рис. 5).

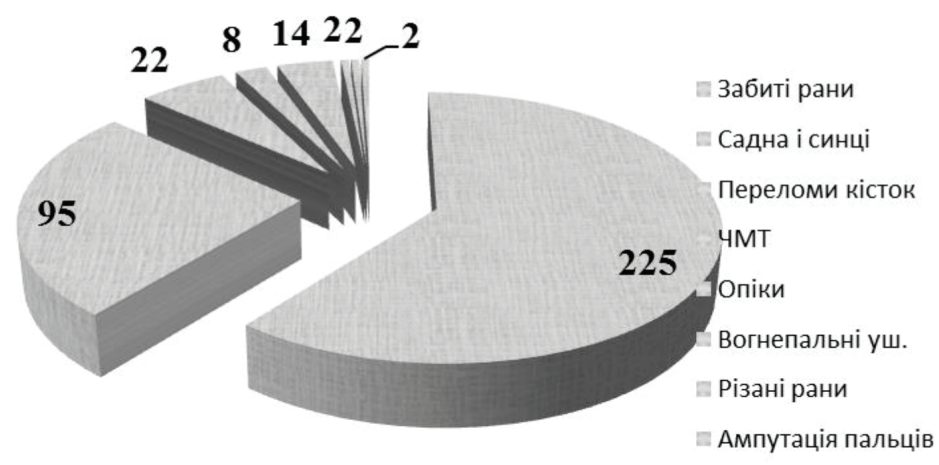

Рис. 5. Види тілесних ушкоджень та їх кількість

Стосовно локалізації ушкоджень - найчастішими об’єктами були нижні кінцівки і голова (рис. 6).

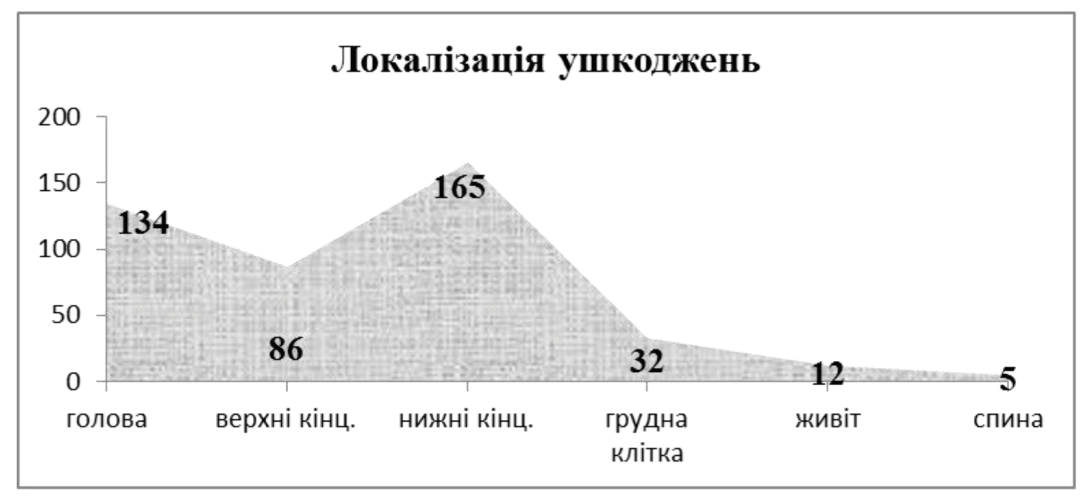

Рис. 6. Локалізація заподіяних ушкоджень

Найбільший обсяг ушкоджень заподіяла вибухова травма. Наслідками розривів світло-шумових гранат були чисельні рани переважно нижніх кінцівок за рахунок утворення уламків від корпусу гранат та додаткових уражаючих компонентів, що умисно і штучно додавались «правоохоронцями» до корпусу гранат. Розриви гранат також супроводжувались термічними, хімічними опіками, контузіями, втратами зору і слуху, що нанесли шкоди здоров'ю найбільшій кількості людей - 133. Значна кількість потерпілих - 55 отримали вогнепальні ушкодження від еластичних куль і картечі до засобів ударно-травматичної (нелетальної) дії до куль, шроту і картечі від вогнепальної зброї та 12 мм металевої кулі типу «Блондо» (рис. 7).

Увагою не можна обійти ушкодження, що були заподіяні тупими предметами: міліцейськими кийками, палками, руками (стиснутими у кулак), ногами у взутті і т.п. Їм, за статистичними даними, належить друге місце (рис. 7).

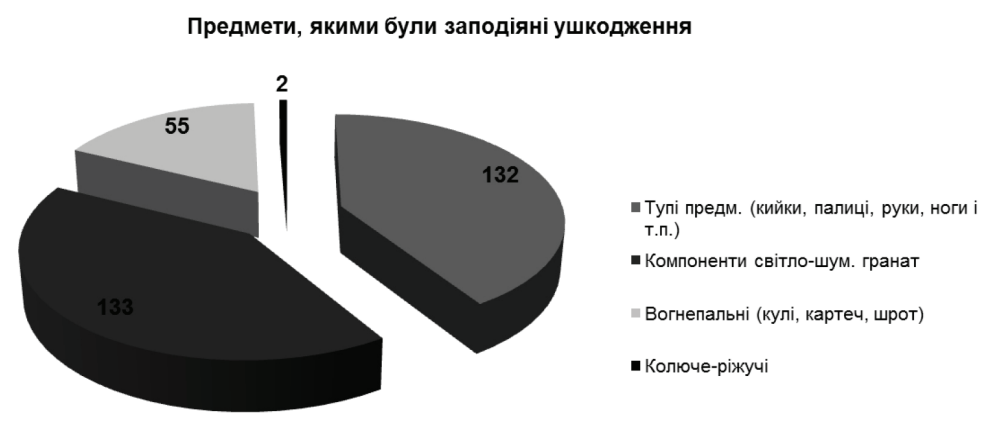

Рис. 7. Предмети, якими були заподіяні ушкодження 
Говорячи про ступінь тяжкості тілесних ушкоджень, слід зазначити, що переважна частина ушкоджень у потерпілих, що були нами обстежені, відносились до легких тілесних ушкоджень та легких тілесних ушкоджень, що спричинили короткочасний розлад здоров'я. Середній ступінь тяжкості отримали 14\% травмованих і тільки у 2 потерпілих він був тяжким (рис. 8).

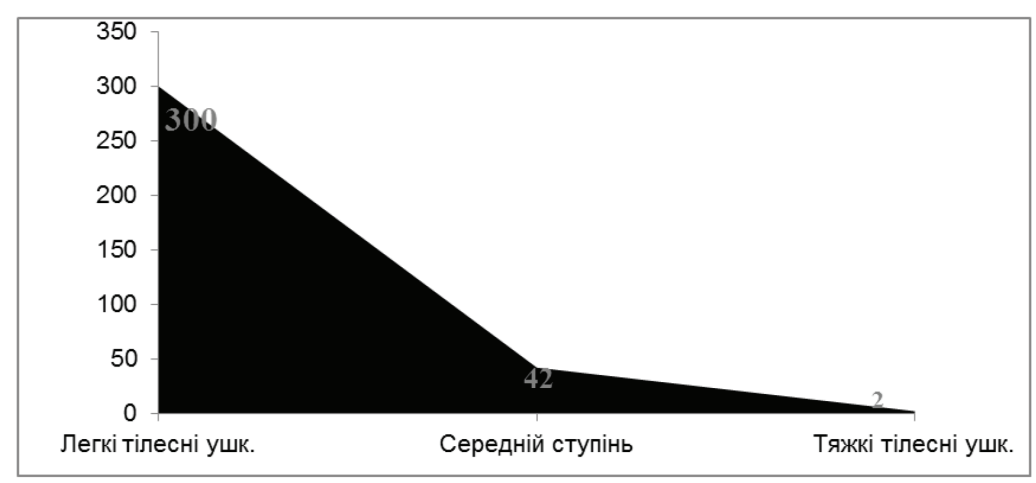

Рис. 8. Ступінь тяжкості, що мав місце у протестувальників Майдану

Такий факт можна пояснити тим, що до нас звернулась лише частина майданівців, оскільки інші сотні потерпілих протестувальників з черепно-мозковими травмами, переломами кісток голови і кінцівок, порушеннями зору, слуху та іншими серйозними ушкодженнями, що супроводжувались довготривалими розладами здоров’я, потребували стаціонарної медичної допомоги і були шпиталізовані у лікувальні заклади.

\section{ВИСНОВКИ.}

1. Найбільша кількість тілесних ушкоджень у протестувальників Майдану, травмованих під час активних подій 18-20 лютого 2014 р., належить вогнепальній травмі, а саме таким її складовим як: садна, крововиливи, рани, спричинені еластичними кулями і картеччю до засобів ударно-травматичної дії та кулями, шротом і картеччю від вогнепальної зброї, 12 мм металевою кулею типу «Блондо», термічні, хімічні опіки, контузії, втрати зору і слуху, травматичні ампутації пальців рук від розриву світло-шумових гранат.

2. Характер, об’єм та переважна локалізація ушкоджень дозволила вважати, що світло-шумові гранати були умисно і штучно споряджені «правоохоронцями» додатковими уражаючими компонентами, наслідками яких стали чисельні рани переважно на нижніх кінцівках.

3. Переважною локалізацією ушкоджень були нижні кінцівки і голова.

4. За ступенем тяжкості переважали легкі тілесні ушкодження.

\section{Література}

1. Михайленко О.В. Особливості ушкоджень тулуба людини боєприпасами «Терен-3ФП» та «АЕ 9», спорядженими еластичними кулями / О. В. Михайленко // Збірник наукових праць НМАПО імені П.Л. Шупика. - Київ. Вип. 16. - Книга 2. - 2007. - С. 490-496.

2. Молчанов В.И. Огнестрельные повреждения // Судебная медицина: Руководство для врачей. - СПб: Гиппократ, 1998. - С. 112-140.

3. О комплексной медико-криминалистической экспертизе огнестрельной травмы / Мазикин И.И., Мовшович А.А.: Мет. письмо. - М., 1989. - 13 с.

4. Попов В.Л., Шигеев В.Б., Кузнецов Л.Е. Судебно-медицинская баллистика. - СПб.: Гиппократ, 2002. - с. 302-328.

5. Мішалов В. Д. Судово-медична оцінка ушкоджень голови і тулуба людини еластичними кулями / В. Д. Мішалов, Ю. П. Шупик, В. Г. Бурчинський і інш. // Збірник наукових праць НМАПО імені П. Л. Шупика. Київ. - 2006. - Вип. 15. - Книга 1. - С. 567-573.

6. Сухий В.Д. Судово-медична характеристика ушкоджень спричинених 9 мм еластичними кулями /В.Д. Сухий// Автореф. дис. ... канд. мед. наук. - Київ, 1999. - 19 с.

7. Черевашко В.В. Вплив перешкоди (скла типу «триплекс») на площу розсіювання картечі / В. В. Черевашко // Український судово-медичний вісник. - 2002. - № 1 (12). - С. 8-10. 


\title{
СУДЕБНО-МЕДИЦИНСКАЯ ОЦЕНКА ПОВРЕЖДЕНИЙ У ПРОТЕСТУЮЩИХ МАЙДАНА
}

\author{
В. Д. Мишалов
}

Резюме. В статье приведены особенности телесных повреждений у протестующих Майдана, которые были выявлены в ходе судебно-медицинского освидетельствования 304 майдановцев, травмированных во время активных событий 18-20 февраля 2014 г. Выявлено, что среди телесных повреждений первое место принадлежит огнестрельном травме, а именно: ссадины, кровоизлияния, раны, вызванные эластичными пулями и картечью к средствам ударно-травматического действия и пулями, дробью и картечью от огнестрельного оружия, 12 мм металлической пулей типа «Блондо», термические, химические ожоги, контузии, потери зрения и слуха, травматические ампутации пальцев рук от разрыва свето-шумовых гранат. Кроме этого, характер, объем и преимущественная локализация повреждений позволила считать, что свето-шумовые гранаты были умышленно и искусственно снабжены «правоохранителями» дополнительными поражающими компонентами, последствиями которых стали многочисленные раны преимущественно на нижних конечностях. Преимущественной локализацией повреждений были нижние конечности и голова. По степени тяжести преобладали легкие телесные повреждения.

Ключевые слова: судебно-медицинская экспертиза, телесные повреждения, огнестрельное травма.

\section{FORENSIC MEDICINE FEATURES INJURIES OF PROTESTERS IN MAIDAN}

\section{Mishalov}

Summary. In the article the features of injuries of protesters in the street that was found during the forensic examination (osviduvannya) 304 persone, injured during active events of 18-20 February 2014 revealed that among the injuries first place belongs to gunshot injury, and that is its integral as abrasions, bleeding, wounds caused by elastic bullets and buckshot to the means of shock-traumatic and balls, meal and buckshot from firearms, $12 \mathrm{~mm}$ steel ball type «Blondeau» thermal, chemical burns, concussion, loss vision and hearing, traumatic amputation of fingers of light bursting noise grenades. In addition, the nature, volume and vast localization injury allowed to believe that light and noise grenades were deliberately and artificially filled with «police» additional damaging components which resulted in numerous wounds mainly in the lower limbs. The predominant localization of injuries were lower extremities and head. Severity prevailed minor injuries.

Keywords: forensic examination, injuries, gunshot injury.

\section{РЕНТГЕНФЛУОРЕСЦЕНТНИЙ СПЕКТРАЛЬНИЙ ЕЛЕМЕНТНИЙ АНАЛІЗ, ЯК ІНСТРУМЕНТ ІДЕНТИФІКАЦІЇ, НА СУЧАСНОМУ РІВНІ ДОСЛІДЖЕННЯ ВОГНЕПАЛЬНОЇ ТРАВМИ}

\author{
(СВ. Д. Мішалов ${ }^{1}$, Т. В. Хохолсва ${ }^{1}$, О. Ю. Петрошак ${ }^{1}$, О. О. Гуріна ${ }^{1}$, \\ Я. В. Чихман ${ }^{1}$, О. В. Гринчишина ${ }^{1}$, О. В. Михайленко \\ Національна медична академія післядипломної освіти імені П. Л. Шупика ${ }^{1}$ \\ Київське міське клінічне бюро судово-медичної експертизи ${ }^{2}$
}

Резюме. Шляхом використання сучасного спектрометру «M4 TORNADO» виробництва компанії Bruker (Нiмеччина) були виявлені нові можливості лабораторної діагностики продуктів пострілу шляхом проведення мікрорентгенівського флуоресцентного спектрального елементного аналізу. Його переваги з аналогічними методами полягають у більшій чутливості виявлення хімічних елементів, що входять до складу факторів, що супроводжіють постріл, таких як - частинки матеріалу, що виносяться з каналу зброї (елементи металу ствола зброї, металеві частини патрону (куля, гільза та капсуль), а також продукти горіння порохових зарядів), у можливості створення карт топографії як загальних карт елементів, так і окремих елементів та їх комбінацій. Наявність 10x та 100x кратних об’єктивів надає можливість проведення прицільного «мікроскопічного» дослідження частини обраної ділянки за топографією елементів на карті.

Ключові слова: мікрорентгенівський флуоресцентний спектральний елементний аналіз; фактори, що супроводжують постріл; вогнепальні ушкодження.

ВСТУП.

Протягом останніх років криміногенна обстановка в Україні характеризується стабільно високим числом злочинів з використанням вогнепальної зброї [1-3]. Цьому сприяють як умови перебування України в стані війни з зовнішнім агресором, що дає можливість нелегального проникнення зброї, так і неупинне удосконалення різних видів ручної вогнепальної зброї та боєприпасів вітчизняного та закордонного виробництва. Серед літературних джерел є багато відомостей про пістолетні боєприпаси, споряджені різними кулями (у тому числі й спеціального призначення), капсулями і порохами, що зокрема досліджувались на кафедрі судової медицини НМАПО імені П. Л. Шупика: 1) 9 мм пістолетними боєприпасами спеціального призначення, спорядженими кулями реактивного 